\title{
Inovasi Pangan Fungsional dan Zero Waste Berbahan Baku Buah Naga
}

\section{Inovasi Pangan Fungsional dan Zero Waste Berbahan Baku Buah Naga}

\author{
Rini Fertiasari ${ }^{1}$, Sri Mulyati ${ }^{2)}$, Ahmad Ridho $^{3)}$ \\ 1,2 Jurusan Agrobisnis, Politeknik Negeri Sambas, Jl. Raya Sejangkung, Kecamatan Sambas, Kabupaten \\ Sambas, Kalimantan Barat 79462 \\ ${ }^{3}$ Jurusan manajemen Informatika, Politeknik Negeri Sambas, Jl. Raya Sejangkung, Kabupaten Sambas, \\ Kalimantan Barat 79462 \\ E_mail : fertia_sari@yahoo.com
}

\begin{abstract}
Sambas regency have 71,15 ha of land dragon fruit with daily production could reach 4 to 5 tons of fruit with 27 times every year. Diversification of products processed red dragon fruit based zero waste started from the problems that arise in the community when the mast. Dragon fruit class $A, A B, B$ can be absorbed by the market, even that becomes products export to malaysia while the class $\mathbf{a B}$ and $\mathrm{B}$ is marketed to the east borneo. Grade $\mathrm{C}$ no consumers in the marketplace. In the quality of the fruits is only small size. Research objectives : 1. Fuctional diversification of food processed tea; 2 . The utilization of the skin fruit as the concept of zero waste; 3 . Know the carbohydrat by different; 4 . Know the amount of calories in a serving of 100 grams of tea; 5 . Increase income the community. The resulting product is a product of refined functional food which has additional functionality as processed food products for health. From the results of the laboratory test, in may the value of carbohidrat by different was $41,83 \%$ and the number of calories was $201,57 \mathrm{kcal} / 100$ grams
\end{abstract}

Keywords : dragon fruit, carbohidrat by different, diversified product, funtional food, zero waste

\section{PENDAHULUAN}

Kabupaten Sambas mempunyai $71,15 \mathrm{Ha}$ lahan buah naga dengan produksi dalam setiap harinya bisa mencapai 4 ton sampai 5 ton buah dengan masa petik hingga 27 kali setiap tahunnya (Dinas Pertanian Sambas, 2015). Buah naga merah adalah salah satu komoditas potensial lokal di Kabupaten Sambas. Pada tahun 2016, Pemerintah daerah Kabupaten Sambas berkeinginan mendaftarkan komoditas buah naga merah menjadi varietas unggul bernama "PIONIR". Buah naga merupakan komoditas potensial di Kecamatan Jawai Kabupaten Sambas. Setiap $1 \mathrm{Ha}$ lahan terdapat 1200 pohon buah naga merah. Pemanenan dilakukan sebulan 2 hingga 3 kali. Berikut adalah luas panen dan produksi buah naga di Kabuapten Sambas tahun 2015 :

Tabel 1 Luas Panen dan Produksi Buah Naga di Kabupaten Sambas Tahun 2015

\begin{tabular}{clccc}
\hline No & Kecamatan & Luas panen $(\mathrm{Ha})$ & Produksi $(\mathrm{Kw})$ & Luas Tanaman yang Belum Menghasilkan (Ha) \\
\hline 1 & Selakau & 2.15 & 128.75 & 0.54 \\
2 & Selakau Timur & - & - & - \\
3 & Pemangkat & - & - & - \\
4 & Salatiga & - & - & - \\
5 & Semparuk & 0 & 0 & 2.50 \\
6 & Tebas & 0 & 0 & 0.80 \\
7 & Tekarang & - & - & - \\
8 & Sambas & 2.63 & 126 & 1.96 \\
9 & Subah & 0.52 & 31.25 & - \\
10 & Sebawi & - & - & - \\
11 & Sajad & - & - & 39.58 \\
12 & Jawai & 25.75 & 2.781 & 11 \\
13 & Jawai selatan & 7 & 420 & 4 \\
14 & Teluk Keramat & 1 & 36 & 0.13 \\
15 & Galing & 0 & 0 & 5.83 \\
16 & Tangaran & 2.50 & 45 & - \\
17 & Sejangkung & - & - & 0.25 \\
18 & Sajingan Besar & 0 & 0 & 3 \\
19 & Paloh & 5 & 20 & 71.15 \\
\hline
\end{tabular}

Sumber : Dinas pertanian dan Peternakan kabupaten Sambas 2015 
Rini Fertiasari, Sri Mulyati, Ahmad Ridho. Inovasi Pangan Fungsional dan Zero Waste Berbahan Baku Buah Naga

Buah naga merah selama ini hanya dimanfaatkan daging buahnya saja, sedangkan kulitnya dibuang sebagai limbah karena dianggap tidak ada manfaatnya. Limbah buah naga merah masih sangat jarang di manfaatkan, apalagi di Kabupaten Sambas. Limbah yang berupa kulit buah naga sebanyak 30 $35 \%$ dari berat buah segar tidak termanfaatkan, padahal kulit buah naga mempunyai kandungan betasianin sebesar 186,90 mg/100 gr berat kering dan aktivitas antioksidan sebesar 53,71 \% ( Herawati, 2013).

Zero waste saat ini semakin dilirik oleh perusahaan-perusahaan dan industri-industri dalam penciptaan produk olahan terutama dari komoditas tanaman hortikultura dan pangan. Zero Waste adalah suatu proses yang dimulai dari produksi sampai berakhirnya suatu proses produksi dengan menghindari terjadinya produksi sampah atau diminimalisir terjadinya .sampah (Wybraniec, S. \& Mizrahi, Y. 2003). Konsep Zero Waste ini salah satunya dengan menerapkan prinsip $3 \mathrm{R}$ (Reduce, Reuse, Recycle). Konsep diversifikasi produk olahan komoditas pertanian berbasis zero waste memiliki beberapa keuntungan, diantaranya adalah meningkatkan nilai tambah produk pertanian dan meningkatkan pendapatan bagi petani dengan cara meminimalisir cost.

Spesifikasi produk yang dikembangkan merupakan produk olahan pangan fungsional buah naga merah berbasis zero waste. Dari segi kandungan nutrisi, dalam 100 gram buah naga merah mengandung kalori $60 \mathrm{kkal}$, protein 0,53 gram, karbohidrat 11,5 gram, serat 0,71 gram, kalsium 134,5 mg, fosfor $87 \mathrm{mg}$, zat besi $0,65 \mathrm{mg}$, vitamin C 9,4 mg, serta kandungan airnya sebanyak $90 \%$. Buah naga merah mengandung banyak nutrisi,vitamin dan mineral. Kandungan itu berupa vitamin $\mathrm{C}$, vitamin B1, vitamin B3, Vitamin B12, kaya serat, mineral (fosfor dan kalsium), antioksida, protein (Pribadi Ys, 2014).

Penelitian ini bertujuan 1. Diversivikasi olahan pangan fungsional berupa teh; 2. Pemanfaatan kulit buah naga sebagai konsep zero waste; 3. Mengetahui karbohidrat by different; 4 . Mengetahui jumlah kalori dalam penyajian 100 gram teh; 5. Meningaktkan pendapatan masyarakat. produk yang dihasilkan merupakan produk olahan pangan fungsional yang mempunyai fungsi tambahan sebagai produk olahan pangan untuk kesehatan

\section{METODE}

Fokus penelitian ini adalah kegiatan pengolahan pangan fungsional yang berkonsep zero waste dari kulit buah naga merah Kabupaten sambas. Faktor yang diamati adalah :

1. Proses Pengembangan produk

2. Pengujian produk yaitu uji proksimat

Data yang digunakan dalam penelitian ini adalah data primer dan data sekunder. Berikut adalah diagram alir prosedur penelitian :

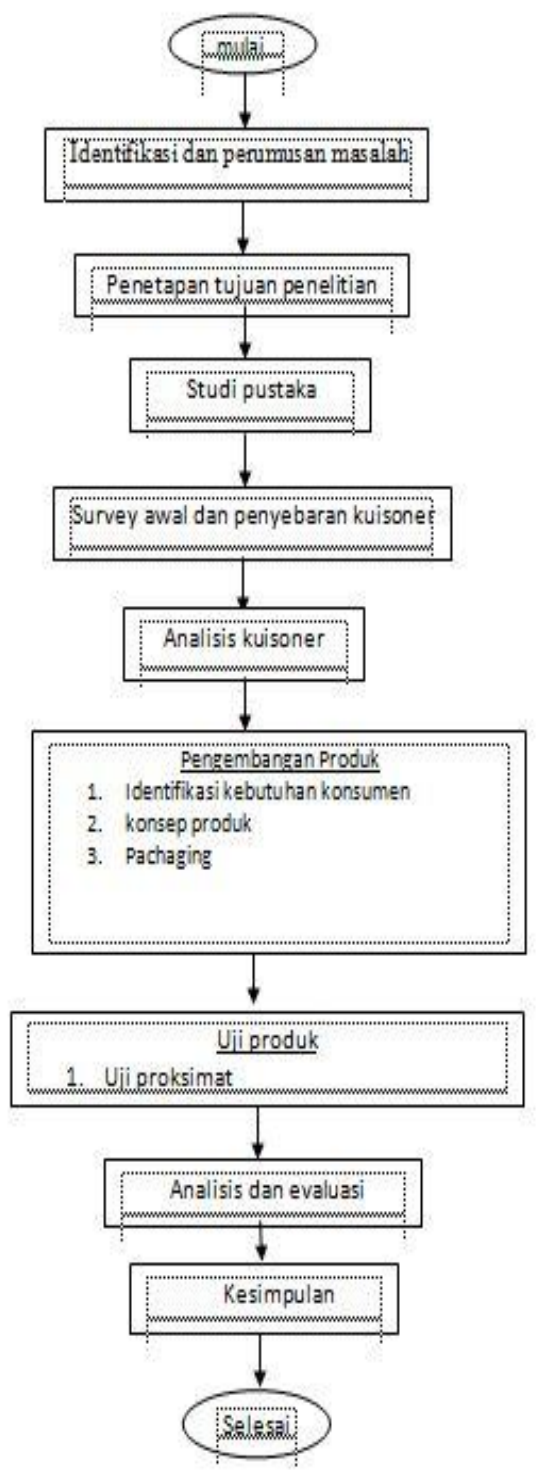

Gambar 1. Diagram alir prosedur penelitian

\section{HASIL DAN PEMBAHASAN}

Pengembangan produk berbasis kulit buah naga merah dilakukan guna memberikan added value kulit buah naga merah yang selama ini menjadi limbah. Pada penelitian ini, pengembangan produk bertujuan untuk menciptakan fungtional food 
berbasis zero waste bagi orang-orang yang membutuhkan sekaligus mengembangkan potensi pangan local yang berbahan baku limbah. Pangan fungsional sendiri mempunyai karakteristik makanan yang praktis, mudah, dan dapat dikonsumsi langsung dengan tetap memperhatikan kandungan nutrisi dan manfaatnya sebagai obat diabetes type 2 .

Pengembangan produk memiliki beberapa tahapan untuk menentukan produk apa yang akan dibuat dan dengan atribut yang bagaimana. Berikut adalah tahapan-tahapan yang dilakukan dalam penelitian pengembangan produk ini.

1. Pemilihan Produk Berdasarkan Preferensi Konsumen

Kuisioner pertama berfungsi untuk mengumpulkan data sebanyak-banyaknya mengenai deskripsi produk kulit buah naga (teh) yang diinginkan konsumen. Pada kuisioner ini dilakukan uji validitas dan reliabilitas tiap butir pertanyaan yang diberikan. Hal ini dilakukan untuk mengetahui sejauh mana tingkat keakuratan pertanyaan tersebut apabila pengujian dilakukan oleh orang lain pada waktu yang berbeda.

Dari pengujian tersebut diperoleh hasil bahwa pertanyaan kuisioner $97,6 \%$ valid dan reliabel. Hanya ada satu pertanyaan yaitu pertanyaan ke duapuluh yang tidak valid mengenai pentingnya informasi pada kemasan baik berupa informasi gizi, berat netto, dan lain sebagainya. Pada uji validitas, butir pertanyaan dinyatakan valid apabila $\mathrm{r}$ tabel $<\mathrm{r}$ hitung, dimana df $=\mathrm{n}-2$ (sig 5\%). Sedangkan dapat dikatakan reliabel apabila nilai alpha $>0,60$. Dari perhitungan pada SPSS diketahui bahwa nilai $r$ hitung pada setiap pertanyaan lebih besar dari $r$ tabel (kecuali pada pertanyaan keduapuluh) dan pada uji reliabilitas nilai alpha lebih besar dari 0,60 sehingga dapat dikatakan valid dan reliabel. Hasil pengujian validitas dan reliabilitas kuesioner I ditunjukkan oleh Tabel 2.

Tabel 2 Hasil Pengujian Validitas dan Reliabilitas KUESIONER I

\begin{tabular}{|c|c|c|}
\hline Butir pertanyaan & Validitas & Reliabilitas \\
\hline pertanyaan 1 & Valid & Reliabel \\
\hline pertanyaan 2 & Valid & Reliabel \\
\hline pertanyaan 3 & Valid & Reliabel \\
\hline pertanyaan 4 & Valid & Reliabel \\
\hline pertanyaan 5 & Valid & Reliabel \\
\hline
\end{tabular}

\begin{tabular}{|c|c|c|}
\hline pertanyaan 6 & Valid & Reliabel \\
\hline pertanyaan 7 & Valid & Reliabel \\
\hline pertanyaan 8 & Valid & Reliabel \\
\hline pertanyaan 9 & Valid & Reliabel \\
\hline pertanyaan 10 & Valid & Reliabel \\
\hline pertanyaan 11 & Valid & Reliabel \\
\hline pertanyaan 12 & Valid & Reliabel \\
\hline pertanyaan 13 & Valid & Reliabel \\
\hline pertanyaan 14 & Valid & Reliabel \\
\hline pertanyaan 15 & Valid & Reliabel \\
\hline pertanyaan 16 & Valid & Reliabel \\
\hline pertanyaan 17 & Valid & Reliabel \\
\hline pertanyaan 18 & Valid & Reliabel \\
\hline pertanyaan 19 & Valid & Reliabel \\
\hline pertanyaan 20 & Tidak Valid & Reliabel \\
\hline pertanyaan 21 & Valid & Reliabel \\
\hline pertanyaan 22 & Valid & Reliabel \\
\hline
\end{tabular}

2. Konsep produk

Berdasarkan identifikasi kebutuhan konsumen yang dilakukan dengan penyebaran kuesioner kepada responden di daerah Sambas dari berbagai karakter dan profesi serta hasil identifikasi fungsi-fungsi produk, maka akan dikembangkan beberapa alternatif konsep teh berbasis kulit buah naga merah. Pengembangan produk ini difokuskan kepada ada tidaknya penambahan jumlah takaran stevia rebau diana.

Komposisi bahan penyusun teh kulit buah naga tidak berbeda untuk tiap konsepnya. Ketepatan komposisi bahan menghasilkan produk teh yang sesuai dengan preferensi konsumen. Empat konsep disiapkan untuk pengembangan produk teh pada penelitian. Konsep-konsep tersebut berasal dari hasil kuisioner. Responden diminta untuk memilih alternatif konsep produk teh kulit naga merah. Konsep produk itu terdiri dari : teh kulit buah naga merah original (tanpa tambahan stevia rebau diana); kulit buah naga (50\%) : stevia rebau diana (50\%); kulit buah naga (60\%): stevia rebau diana (40\%); kulit buah naga $(75 \%)$ : stevia rebau diana $(25 \%)$

\section{Uji proksimat}

Tahap analisis selanjutnya adalah pengujian laboratorium untuk sampel teh kulit buah naga merah original. Tahap ini diperlukan untuk 
Rini Fertiasari, Sri Mulyati, Ahmad Ridho. Inovasi Pangan Fungsional dan Zero Waste Berbahan Baku Buah Naga

mengecek kualitas teh kulit buah naga merah yang diproduksi dan melakukan perbaikan apabila diperlukan. Salah satu cara analisis evaluasi teh kulit buah naga merah adalah dengan pengujian proksimat

TABEL 3

HASIL ANALISA TEH KULIT BUAH NAGA MERAH ORIGINAL

\begin{tabular}{|l|l|l|c|c|}
\hline No & Sampel/Kode & \multicolumn{1}{c|}{$\begin{array}{c}\text { Macam } \\
\text { Analisa }\end{array}$} & \multicolumn{2}{|c|}{ Hasil Analisa } \\
\cline { 4 - 5 } & & Uir (\%) & 11,46 & 11,43 \\
& & Teh Kulit & Al 2 \\
& buah naga & Abu (\%) & 12,48 & 12,52 \\
& original & Lemak & 0,91 & 0,90 \\
& & $(\%)$ & 4,51 & 4,46 \\
& & Protein & 28,63 & 29,00 \\
& & total, fk: & 329,66 & 336,0 \\
& & 6,25 (\%) & & 0 \\
& & Serat & & \\
& & Kasar (\%) & & \\
& & Vitamin C & & \\
\cline { 4 - 5 } & & (mg/100g) & & \\
\hline
\end{tabular}

Sumber : Laboratotium Uji Teknologi

Pangan dan Hasil Pertanian 2017

Karbohidrat by different

$=100-($ kadar air + abu + protein + lemak + serat kasar) \%

$=100-(11,45+12,5+4,49+1,81+28,82) \%$

$=41,83 \%$

Kalori total dalam teh kulit buah naga merah $=$ karbohidrat by different $(\mathrm{kkal})+$ protein $(\mathrm{kkal})+$ lemak (kkal)

$=(41,83 \times 4)+(4,49 \times 4)+(1,81 \times 9)$

$=167,32+17,96+16,29$

= 201,57 kkal per 100 gram

Nilai kalori total adalah total energi yang diperoleh apabila mengkonsumsi produk tersebut dalam suatu satuan massa atau berat. Berdasarkan perhitungan di atas, didapatkan hasil kalori total adalah 201,57 kkal/100 g. Perhitungan karbohidrat dilakukan dengan metode karbohidrat by different. Rumus perhitungan karbohidrat by different adalah seperti tertulis di atas.

\section{KESIMPULAN}

1. Salah satu jenis olahan yang dapat dibuat dari limbah kulit buah naga, adalah teh kulit buah naga.

2. Pengolahan kulit buah naga merah menjadi teh herbal memberikan nilai tambah dari segi fungsi, nilai ekonomis, rasa, estetika, dan manfaat.
3. Kelebihan produk teh herbal kulit buah naga merah adalah kemudahan mengkonsumsi, mudah untuk didistribusikan, dan memiliki kandungan nutrisi yang cukup.

4. Nilai carbohidrat by different $41,83 \%$ dan nilai kalori dari 100 gram teh kulit buah naga merah adalah 201,57 kkal per 100 gram

\section{DAFTAR PUSTAKA}

[1] Azwar, S. 1997. Reliabilitas dan Validitas. Pustaka Pelajar. Yogyakarta.

[2] Citramukti, I. 2008. Ekstraksi dan Uji Kualitas Pigmen Antosianin pada Kulit Buah Naga Merah, skripsi, Jurusan THP Universitas Muhammadiyah Malang, Malang

[3] Hasrudin, S. 2017. Mutu Kimia dan Organoleptik Pasta Kulit Buah Naga Hasil Fermentasi Dengan Berbagai Macam Ragi. Jurnal agroland 24 (1) : 57 - 63, April 2017. [4] Pribadi, Y.S., Sukati Ningsih dan Sari, P., 2014. Formulasi tablet Effervescent Berbahan Baku Kulit Buah Naga Merah Dan Buah Salam. Berkala Ilmiah Pertanian. Volume 1, Nomor 4 Mei 2014 